\title{
The Resilience of Rural Tourism and Adjustment Measures for Surviving The COVID-19 Pandemic: Evidence from Bromo Tengger Semeru National Park, Indonesia
}

\author{
Novi Meilana Sari ${ }^{1}$, Iwan Nugroho ${ }^{1, *}{ }^{*}$, Evi Nurifah Julitasari ${ }^{1}$, Rita Hanafie ${ }^{1}$
}

\author{
AFILIATIONS \\ 1. Widyagama University of \\ Malang \\ * Correspondence: \\ iwanuwg@widyagama.ac.id
}

RECEIVED 2021-09-13 ACCEPTED 2021-12-13

COPYRIGHT @ 2022 by Forest and Society. This work is licensed under a Creative Commons Attribution 4.0 International License

\begin{abstract}
The COVID-19 virus pandemic has generated an unprecedented impact on all aspects of life, including rural tourism. This study aims to study the impact of the COVID-19 pandemic on the performance of homestay businesses in Gubukklakah Village, Malang Regency, and their adjustment measures to get out of the pandemic. A survey research with descriptive and quantitative approaches was conducted on 47 active homestay owners. $98 \%$ of the respondents stated that the pandemic affected their homestay business activities. About $44.6 \%$ of them said that the pandemic would not last long, while more than $50 \%$ of them said that the pandemic would last a long time. The pandemic has decreased the number of active homestays from 47 to 11 , coupled with an $81 \%$ decline in income. Due to the pandemic, about $85.1 \%$ of the respondents returned to farming activities. The study suggests several actions that can be done to respond to the pandemic, namely the application of health protocols in various activities, the provision of cash or non-cash assistance to pandemic affected families, the strengthening of the agricultural sector and skilled human resources in tourism services, and the innovation of outdoor tourism products based on local uniqueness.
\end{abstract}

\section{KEYWORDS}

Bromo; homestay; national park; rural tourism; pandemic

\section{INTRODUCTION}

The COVID-19 pandemic has generated an unfathomable impact. The pandemic has crippled the economies of many countries, burdening almost all economic and social sectors. Measures to cope with the pandemic in all countries rely on the standardized health measures of testing, quarantines, and the complete closure of borders, resulting in all social and economic activities being disrupted. Meanwhile, the implementation of the vaccination has been slower than expected, further delaying economic recovery efforts, which may create a more severe economic crisis (UNWTO, 2021).

The COVID-19 pandemic has impacted the tourism sector all over the world (Harchandani \& Shome, 2021). The pandemic reduced the flow of tourist arrivals worldwide by $87 \%$, marking 2020 the worst year in tourism history. Due to various restrictive regulations in many countries, the flow of tourists in the Asia Pacific region has decreased by $96 \%$ (UNWTO, 2021).

Because the tourism sector is multi-sectoral, many other economic activities depend on tourism. Due to this, many sectors have been paralyzed. The pandemic caused Indonesia's 2020 economic growth to decline by 2.1\% (BPS, 2021). The BPS (Central Bureau of Statistics) survey (BPS, 2020b) revealed that $14.1 \%$ of the existing companies stopped operating and $11.6 \%$ of them reduced their workforce. Meanwhile, the hotel occupancy rate decreased significantly from $56.73 \%$ to $28.07 \%$ during the period from July 2019 to July 2020. Tourist destinations in Bali, North Sulawesi (Manado) and the Special Region of Yogyakarta (DIY) were the hardest hit. The 
pandemic reduced state revenues in the tourism sector by 20.7 billion dollars (Kementerian Pariwisata, 2020).

Before the pandemic, all countries including Indonesia enjoyed abundant benefits from tourism activities. In Indonesia, the tourism sector in many regions has been developed by relying on natural attractions, local cultures and local uniqueness (Nugroho, 2010; Nugroho \& Negara, 2015). Tourism actors are able to package attractions skillfully and include some educational elements into a business that considers the cultural heritage, participation and welfare of the local people, and that incorporates efforts to conserve natural resources and the environment (Nugroho et al., 2018). Tourism, especially ecotourism, can harmonize the preservation of the natural environment and economic development by adhering to the principle of community-based ecotourism (Setokoe \& Ramukumba, 2020; Tolkach \& King, 2015).

The establishment of rural tourism by involving community participation is a challenging work. In various countries, many people engage with tourism businesses and make a living according to their conditions and abilities (Chin \& Pehin Dato Musa, 2021; Coroș et al., 2021; Fountain, 2021; Gascón \& Mamani, 2021; López et al., 2018; Saraithong \& Chancharoenchai, 2014; Sunkar et al., 2016; Vaishar \& Štastná, 2020). Communities can be involved in the management of tourist attractions, accommodations and supporting facilities that integrate the prevailing traditions. Learning experiences can be provided for villagers, so that they become more productive and get added value. Communities need empowerment to explore their abilities, become participants in the development of rural tourism, and manage their resources (Nugroho et al., 2020, 2021; Rasid et al., 2012; Sunkar et al., 2016).

Bromo Tengger Semeru National Park (BTSNP) is a very popular tourist destination and provides opportunities for rural people in the surrounding areas to take a role in tourism-based activities (Hakim et al., 2019; Krisnanto, 2021; Mujanah et al., 2015; Nugroho \& Negara, 2015; Pratiwi et al., 2019; Rouf et al., 2018). Due to its status as a protected area, BTSNP requires very high attention to sustain natural resource management. Gubukklakah is one of the villages around BTSNP, where the people engage in various tourism activities, including meeting the needs of visitors (Prakoso, 2017; Purmada et al., 2016; Puspitasari et al., 2017). In the village, there are 61 homestays organized by the Tourism Village Institute (Ladesta). Homestay services are an essential measure of how tourism hospitality is presented and the variety of tourist activities delivered, while at the same time reflecting visitors' satisfaction and the welfare of local people (Kumar et al., 2012; Samsudin \& Maliki, 2015; Saraithong \& Chancharoenchai, 2014).

Gubukklakah Village then developed rapidly and received many tourist visits. Tourists stay at the homestays and enjoy trekking and tourist attractions in the BTSNP area. People carry out farming activities and serve tourists in a harmonious and synergistic situation. A study by Puspitasari et al. (2017) revealed that there was a significant increase in people's income from tourism service activities, including tourist attractions, tour guides, tour trips, food and beverages, accommodations and tourism transportation, organized by Ladesta Gubukklakah. In 2014, Gubukklakah Tourism Village was awarded as one of the best 10 rural tourism destinations at the national level (Ladesta Gubukklakah, 2021).

However, the COVID-19 pandemic has also impacted tourism activities in Gubukklakah Village. The government's policy of implementing social distancing has resulted in a decrease in domestic and foreign tourist visits. At the beginning of the 
pandemic (April 2020), the government stopped tourist visits to BTSNP. Then it was open briefly at the end of 2020 , but closed again due to a spike in virus transmission. As a result, Gubukklakah villagers had to deal with such changes and uncertainties, affecting their economic activities. They then returned to farming as before, doing horticultural and annual crop plantation farming. This situation is also happening in many other tourism destinations in Bali and other regions. For many people in those areas, a plausible way to get out of the pandemic crisis is to return to agriculture as the safest option in which they have complete control over their own lives in devoting themselves to crop production (Gascón \& Mamani, 2021).

Researching homestay owners' lives during the pandemic can provide a comprehensive view of their perceptions of tourism, the pandemic and its impact on wellbeing. This study has some novelty in that it highlights homestay businesses rather than homestay studies (Gascón \& Mamani, 2021; Ratuva, 2021). The study provides guidance on ways to develop relevant programs and manage tourism businesses properly during the COVID-19 pandemic, especially in rural areas. The study also provides lessons for designing relevant post-pandemic policies, including how to strengthen farming businesses in rural tourism areas. The post-pandemic situation requires us to rethink or justify how to transform tourism in the future (Brouder, 2020), develop innovation and rebuild trust, and develop tourism cooperations between countries emphasizing safe travel and health protocol.

The study aims to investigate homestay owners' perceptions of the COVID-19 pandemic, the impact of the pandemic on homestay business income, and the levels of adjustment made by homestay owners during the pandemic to support their livelihoods.

\section{RESEARCH METHODS}

This study was conducted in Gubukklakah Village, Poncokusumo Sub-district, Malang Regency. Gubukklakah Village is the rural tourism area that has the highest number of homestays in Poncokusumo Sub-district and has grown relatively fast compared to other villages (BPS, 2020a).

The study used a descriptive and quantitative approach to explore the situations faced by homestay business actors in connection with the COVID-19 pandemic. 47 people running homestay businesses in Gubukklakah Village were interviewed to obtain data on the variables of their perceptions of the COVID-19 pandemic, income, and business related efforts made during the pandemic. The study was conducted from February to April 2021. The study also took data on related conditions before the pandemic documented from the beginning of 2019 to the start of the pandemic (April 2020).

Close-ended questions were used as interview instruments, providing answers from 'strongly disagree' to 'strongly agree', with scores on a Likert scale from 1 to 5. Interviews were also conducted with community leaders to obtain more complete tourism information and corroborate the interview results. A review of secondary data was also conducted.

A descriptive analysis was carried out to identify phenomena or relationships between variables by tabulating and grouping responses or perceptions regarding the pandemic and the adjustments that the homestay owners made to their works. The variables of the perception of the pandemic include questions about the impact of the pandemic on homestay business activities, tourist visits, and homestay income; policy 
information in the tourism sector related to the pandemic; the application of health and safety protocols; and the duration of the pandemic. The variables of the adjustment made include questions related to the losses generated, efforts to recover from the pandemic crisis, and choices to work in agriculture and other sectors.

A quantitative analysis was carried out to examine phenomena or relationships between variables by using t-tests to measure differences in income before and after the pandemic. A binary logistic regression analysis was carried out to estimate the factors influencing the adjustment made by homestay owners to return to farming $(\mathrm{Y} 1 / \mathrm{Y} 0)$ due to the pandemic, using the following function:

$$
f\left(\frac{Y 1}{Y 0}\right)=a+b X_{i}+e_{i}
$$

in which the decision function to return to farming is influenced by the variable $X i$ and error (ei). The independent variable $\mathrm{Xi}$ consists of sex, age, education, employment income, the perception of the duration of the pandemic and the experience of managing a homestay.

\section{RESULTS AND DISCUSSION}

\subsection{Gubukklakah Village Overview}

Gubukklakah Village is administratively located in the area of Poncokusumo Sub-district, Malang Regency, and is categorized as a buffer zone for the BTSNP area. The physiography of the village is hilly and undulating. The village is situated in the Bromo mountain complex with air temperatures ranging from $20^{\circ} \mathrm{C}$ to $22^{\circ} \mathrm{C}$. The village covers an area of 384 ha, with dominant land use (85\%) for horticulture and seasonal crop cultivation (BPS, 2020a).

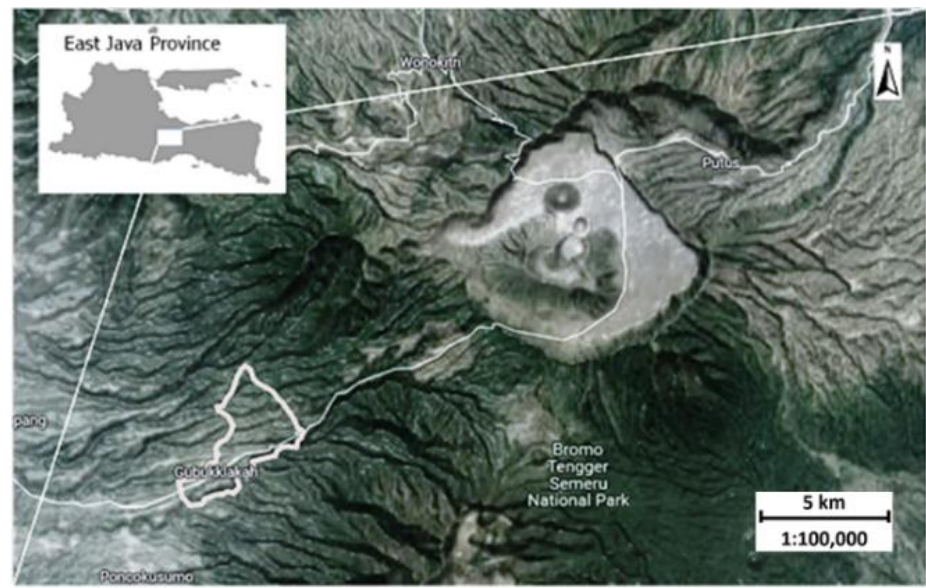

Figure 1. Gubukklakah Village Map (google maps)

The village population is 3,734. There are 962 family heads in the village. The population works mainly as farmers (36\%) and farm laborers (27\%). Most of the population (53\%) has primary education, while less than $1 \%$ of it has university education. A total of 172 families (18\% of the population) are categorized as poor 
families (Ladesta Gubukklakah, 2021).

The village is blessed with a beautiful landscape with a variety of waterfalls and sunrise spots, and it offers white water rafting and agrotourism focusing on horticultural commodities (BPS, 2020a). The various attractions in BTSNP encouraged the village community to take a role in tourism activities. In 2010, the community established a tourism village institution (Ladesta) to organize, develop and operate tourism activities (Ladesta Gubukklakah, 2021).

Ladesta is spearheaded by youths who care about improving the welfare of the population who generally live as farmers. Ladesta, through various programs, empowers the community, so that it can carry out tourism activities successfully. The programs carried out by Ladesta include the provision of guidance on apple picking agrotourism, homestay management training, homestay building arrangement, and hospitality training on how to provide comfortable services to visitors. Furthermore, Ladesta also manages visits, organizes tourist activities and makes arrangements for the accommodation for tourists.

Initially, 68 houses were prepared as homestays. However, with time, their number has decreased. Now there are 47 homestays that are actively operating. Gubukklakah Village has the highest number of homestays compared with the other villages in Poncokusumo Sub-district (BPS, 2020a). In general, tourism development efforts in Gubukklakah village are expected to strengthen the economy, create prosperity, and increase farm productivity in the village.

\subsection{Characteristics of the Respondents}

This study collected data on the owners of homestays in Gubukklakah Village that are actively operating. The number of the respondents is 47 . Most of them $(72.3 \%)$ are male. Most of them (57.5\%) have primary education and $38.3 \%$ of them are high school graduates. Most of the respondents (87.2\%) are over 50 years old. Most of them (46.8\%) work as farmers, followed by those who are housewives $(27.7 \%)$ and those who work as traders (23.4\%).

Table 1. Characteristics of the Respondents (Homestay Owners)

\begin{tabular}{|c|c|c|c|c|c|}
\hline Variable & People & Proportion & Variable & People & Proportion \\
\hline & & $\%$ & & & $\%$ \\
\hline Age & & & Sex & & \\
\hline $15-40$ years & 1 & 2.1 & Male & 34 & 72.3 \\
\hline 41-50 years & 5 & 10.6 & Female & 13 & 27.7 \\
\hline $51-60$ years & 23 & 48.9 & Occupation & & \\
\hline$>60$ years & 18 & 38.3 & Farmer & 22 & 46.8 \\
\hline Education level & & & Self-help employee & 11 & 23.4 \\
\hline Elementary school & 27 & 57.4 & Teacher & 1 & 2.1 \\
\hline Junior High School & 1 & 2.1 & Housewife & 13 & 27.7 \\
\hline Senior High School & 18 & 38.3 & Working experience & & \\
\hline University & 1 & 2.1 & 7 years & 3 & 6.4 \\
\hline Number of visitors & & & 8 years & 8 & 17.0 \\
\hline$<50$ people & 10 & 21.3 & 9 years & 7 & 14.9 \\
\hline 51-100 people & 25 & 53.2 & 10 years & 25 & 53.2 \\
\hline 101-250 people & 9 & 19.1 & 11 years & 4 & 8.5 \\
\hline >250 people & 3 & 6.4 & & & \\
\hline
\end{tabular}

Table 1 also shows the number of visits at homestays for one year, from the beginning of 2019 to the beginning of the pandemic (April 2020). During the period, 
there were a total of 4,428 visits. $53.2 \%$ of the respondents received 50 to 100 guests. Three respondents served more than 250 guests. The highest visit record was 360 visitors, who stayed at a homestay. Furthermore, $61.7 \%$ of the respondents have operated a homestay business for 10-11 years or since the village was officially launched in 2010 as a tourism destination.

The description shows that homestays in Gubukklakah Village receive relatively high visits of tourists. In the period 2014-2017, the number of visits was over 5000 guests per year (Puspitasari et al., 2017). This record of visits shows that the rural tourism developed in the village has surpassed the rural tourism in Candirejo, Magelang (Nugroho \& Negara, 2014), which was developed earlier. This indicates that the tourism activities in Gubukklakah Village, which focus on homestay services, have been organized very well (Kumar et al., 2012; Samsudin \& Maliki, 2015; Saraithong \& Chancharoenchai, 2014). Even though the demographic data indicates that the age ranges and education levels of the respondents are less supportive of tourism businesses, tourism services in the village run optimally. Environmental factors, beautiful landscapes and hospitality are the advantages of village tourism attracting tourists (Coroș et al., 2021). The learning and empowerment provided by Ladesta have contributed to the success of tourism activities in the village. Homestay owners have been able to learn and develop themselves positively in operating tourism activities and managing their available resources (Nugroho et al., 2020, 2021; Rasid et al., 2012).

\subsection{Perception of the COVID-19 Pandemic}

How the respondents perceived the pandemic are presented in Table 2. Almost $98 \%$ of the respondents agreed and highly agreed that the pandemic affected their homestay business activities. They also revealed that the pandemic also decreased the number of visitors and their homestay income. All the respondents received information about tourism policies related to the pandemic. The information was provided by Ladesta. Most of the respondents were committed to implementing health protocols in providing tourism services.

Table 2. Perception of the Homestay Owners in Gubukklakah Village of the COCID-19 Pandemic

\begin{tabular}{|c|c|c|c|c|c|}
\hline Variable questioned & SDA & DA & M & A & SA \\
\hline & \multicolumn{5}{|c|}{ 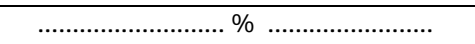 } \\
\hline 1. The pandemic has affected homestay activities & 0 & 0 & 2.1 & 46.8 & 51.1 \\
\hline 2. The pandemic has affected tourist visits & 0 & 0 & 0 & 46.9 & 53.1 \\
\hline 3. The pandemic has affected homestay income & 0 & 0 & 0 & 46.9 & 53.1 \\
\hline $\begin{array}{l}\text { 4. You have got information on tourism sector } \\
\text { policies related to the pandemic }\end{array}$ & 0 & 0 & 0 & 61.7 & 38.3 \\
\hline $\begin{array}{l}\text { 5. Ladesta has provided information on tourism } \\
\text { sector policies related to the pandemic }\end{array}$ & 0 & 0 & 0 & 57.5 & 42.5 \\
\hline $\begin{array}{l}\text { 6. You have implemented health protocols in } \\
\text { providing tourism services }\end{array}$ & 0 & 2.1 & 0 & 76.6 & 21.3 \\
\hline 7. The pandemic will last for a long time & 0 & 44.6 & 4.3 & 21.3 & 29.8 \\
\hline
\end{tabular}

SDA=strongly disagree, $\mathrm{DA}=$ disagree, $\mathrm{M}=$ moderate, $\mathrm{A}=$ agree, $\mathrm{SA}=$ strongly agree Kruskal Wallis Test: Chi-Square 37.527, degree of freedom 6, Sign. 0.000

The respondents showed mixed responses to the question about the duration of the pandemic. About $44.6 \%$ of the respondents stated that the pandemic would not last long (disagree), while more than $50 \%$ of them stated that the pandemic would 
last a long time (agree and highly agree).

Questions 1 to 6 ask about the respondents' behavior towards the impact of the pandemic that they really feel empirical. It is not surprising that all of them responded with 'agree' and 'strongly agree'. However, question 7 indicates the uncertain end of the pandemic. The respondents provided mixed or biased responses to the question.

Essential findings in Table 2 show that the respondents received appropriate information and channels regarding tourism policies made by the government. The decline in the number of homestay visitors was strongly influenced by BTSNP's decision to stop tourist visits whenever there was an increase in virus transmission. Such a situation could be handled properly with measures carried out together by BTSNP, the village government, and Ladesta. The policy to stop tourist visits has proven to be effective in reducing the spread of COVID-19, although it has negatively affected tourism.

Travel or tourism activities, especially tours, airport activities, and transportation, will lead to physical contact and create crowds. Even though tourism activities are carried out with health and safety protocols, the fear of the spread of the COVID-19 virus is so high that many trips have been cancelled (Bratic et al., 2021; Harchandani \& Shome, 2021; Zheng et al., 2021)

\subsection{Impact of the COVID-19 Pandemic on Homestay Income}

The COVID-19 pandemic has generated a significant impact on the performance of homestay businesses in Gubukklakah Village. Table 3 shows that the numbers of active homestays, guests and occupied rooms have decreased by $77 \%, 96 \%$, and $83 \%$ respectively. Even though the room rates have not changed, the impact of the pandemic is certainly detrimental to homestay business.

Table 3. Homestay Business Performance Before and After the Pandemic

\begin{tabular}{lcrr}
\hline \multicolumn{1}{c}{ Variable } & Unit & \multicolumn{1}{c}{ Before } & \multicolumn{1}{c}{ After } \\
\hline 1. Number of active homestays & homestay & 47 & 11 \\
2. Number of guests & people & 4,428 & 194 \\
3. Occupied rooms & room & 232 & 39 \\
4. Room rates & rupiahs & 150,000 & 150,000 \\
\hline
\end{tabular}

The calculation period started from the beginning of 2019 to the beginning of the pandemic (April 2020)

The t-statistical test was employed to see the differences between the homestay performance before the pandemic and the one after the pandemic in terms of the average number of guests and income per homestay (Table 3 and Table 4). The results show that there was a significant decrease $(p$-value $<0.01)$ in these two variables. The average number of guests decreased by $81 \%$ from 94.2 to 17.6 people per homestay. Meanwhile, the total income also decreased by $81 \%$ from 14.21 million to 2.65 million rupiahs per homestay. Before and during the pandemic, a homestay owner received an average monthly income of 1.18 million rupiahs and 220 thousand rupiahs respectively. 
Table 4. Statistical Test of the Average Number of Visitors and Income per Homestay

\begin{tabular}{lrrrr}
\hline Variable & \multicolumn{1}{c}{ Means } & Std. Error Mean & \multicolumn{1}{c}{$\mathrm{t}$} & P-value \\
\hline The visitors (people) & & & 3.206 & 0.002 \\
$\quad$ Before the pandemic & 94.21 & 11.405 & & \\
$\quad$ After the pandemic & 17.64 & 5.685 & & \\
Income (rupiah) & & & 3.242 & 0.002 \\
$\quad$ Before the pandemic & $14,217,021.28$ & $1,704,119.917$ & & \\
$\quad$ After the pandemic & $2,645,454.55$ & $852,681.720$ & & \\
\hline
\end{tabular}

The calculation period started from the beginning of 2019 to the beginning of the pandemic (April 2020)

The COVID-19 pandemic also has significant social implications. The implications include situations of uncertainty, unemployment, and a decline in welfare (FAO, 2020). However, the impact of the pandemic can provide benefits for strengthening agricultural activities. This effort puts the workforce fully in control of agricultural production that was previously diversified into tourism activities (Gascón \& Mamani, 2021). This is also part of adaptation or resilience derived from social values to solve the economically paralyzing impacts of the pandemic (Ratuva, 2021).

\subsection{Adjustment to the COVID-19 Pandemic}

Homestay owners show adaptive behavior in the face of the pandemic for the sake of the sustainability of their lives. Table 5 shows that $87.3 \%$ of the respondents agreed and strongly agreed that they were harmed by the pandemic, while only $2.1 \%$ of them did not feel the impact of the pandemic. Most of them (95.7\%) made an effort to escape from this unfavorable condition. Furthermore, about $85.1 \%$ of the respondents went back to their farming businesses. Approximately $76.6 \%$ of the respondents stated that they had other jobs due to the decline in tourism activities.

Table 5. Homestay Owners' Adjustment to the COVID-19 Pandemic

\begin{tabular}{lccccc}
\hline Variable questioned & SDA & DA & M & A & SA \\
\hline & $\ldots \ldots \ldots \ldots \ldots \ldots \ldots \ldots . \ldots \ldots \ldots \ldots \ldots \ldots \ldots \ldots$ \\
1. You are suffering losses during this pandemic. & 0 & 2.1 & 10.6 & 40.5 & 46.8 \\
2. You are trying to get out of the situation. & 0 & 2.1 & 2.1 & 59.5 & 36.2 \\
3. You work on a crop production farm. & 0 & 14.8 & 0 & 44.6 & 40.5 \\
4. You have another job during the pandemic. & 0 & 21.2 & 2.1 & 59.5 & 17.1 \\
\hline
\end{tabular}

SDA=strongly disagree, $\mathrm{DA}=$ disagree, $\mathrm{M}=$ moderate, $\mathrm{A}=$ agree, $\mathrm{SA}=$ strongly agree

Kruskal Wallis Test: Chi-Square 11.989, degree of freedom 3, Sign. 0.007

This finding shows that farming may function as a kind of life support when tourism activities are under pressure or undergoing changes. This confirms the importance of synergizing the agricultural sector with tourism development initiatives in rural areas. In reality, people show that farming is the main source of livelihood with an allocation of at least five days a week, while tourism business activities are generally established on weekends. Working in farming and tourism contribute to the welfare of the villagers very significantly, with an increase in income equivalent to 1.7 times in comparison to working in farming only (Purnomowati et al., 2012).

It should be noted that rural tourism activities are mostly intermittent. Therefore, the uncertainty on tourist visits is common in a tourism destination. Due to this, during the pandemic, many people have chosen a safe way, i.e. returning to farming, which is an investment of time and capital (Gascón \& Mamani, 2021). As stated by Ratuva (2021), the pandemic has proven to deteriorate the economic infrastructure that is relied upon in rural life. Returning to local values of agricultural 
life has proven to be effective and durable in strengthening social ties and ensuring that no one in the community suffers from lockdowns, unemployment, and lack of access to resources.

This study also tries to find out the socio-economic and demographic factors that influence the homestay owners' decision to return to farming during the pandemic, as presented in Table 6 . By using the binary logistic regression function, it is found how the estimated variables affect the decision to return to farming $(=1,0$ others).

The Hosmer and Lemeshow statistical test shows that the model meets the goodness of fit, so that it may explain the relationships between the variables. The variable that significantly affected the decision to go back to farming is the income before the pandemic $(p=0.065)$, while other variables showed no significant effect ( $p>0.100)$. The significant effect of the income on the choice of working in farming is shown by Khaafidh \& Poerwono (2013). They also show that age, education, land ownership, and farming experience significantly influence an individual's decision to work in agricultural activities.

Table 6. Variable Estimates Affecting the Homestay Owners' Decision to Return to Farming

\begin{tabular}{|c|c|c|c|c|c|c|}
\hline \multirow{2}{*}{ Variable estimate } & \multirow{2}{*}{$\begin{array}{l}B=\text { coeffi- } \\
\text { cient }\end{array}$} & \multirow{2}{*}{ Wald } & \multirow{2}{*}{ Sig } & \multirow{2}{*}{$\operatorname{Exp}(B)$} & \multicolumn{2}{|c|}{ 95\% C.I.for EXP(B) } \\
\hline & & & & & Lower & Upper \\
\hline Constant & 0.339 & 0.002 & 0.963 & 1.404 & & \\
\hline $\begin{array}{l}\text { Sex (1=female, } \\
0=\text { male) }\end{array}$ & -2.636 & 1.244 & 0.265 & 0.072 & 0.001 & 7.362 \\
\hline Age (years,) & -0.092 & 0.660 & 0.417 & 0.912 & 0.730 & 1.139 \\
\hline $\begin{array}{l}\text { Education ( } 0=S D \text {, } \\
\text { 1=SMP, 2=SMA or } \\
\text { above) }\end{array}$ & -0.625 & 0.427 & 0.514 & 0.535 & 0.082 & 3.492 \\
\hline $\begin{array}{l}\text { Income before the } \\
\text { pandemic (rupiah) }\end{array}$ & 0.000 & 3.404 & 0.065 & 1.000 & 1.000 & 1.000 \\
\hline $\begin{array}{l}\text { Income during the } \\
\text { pandemic (1=yes, } \\
0=\text { no) }\end{array}$ & -2.313 & 2.216 & 0.137 & 0.099 & 0.005 & 2.079 \\
\hline $\begin{array}{l}\text { Occupation ( } 1= \\
\text { farmer, } 0=\text { other) }\end{array}$ & 2.300 & 2.127 & 0.145 & 9.974 & 0.453 & 219.449 \\
\hline $\begin{array}{l}\text { Perception of the } \\
\text { duration of the } \\
\text { pandemic } \\
\text { (0=shortly, } \\
1=\text { =medium, } 2=\text { long, } \\
3=\text { longer) }\end{array}$ & -0.301 & 0.375 & 0.540 & 0.740 & 0.282 & 1.940 \\
\hline $\begin{array}{l}\text { Working experience in } \\
\text { homestay (years) }\end{array}$ & 0.679 & 1.254 & 0.263 & 1.972 & 0.601 & 6.471 \\
\hline
\end{tabular}

Omnibus Tests: Chi-square $=17.884, \mathrm{df}=8$, Sign. 0.022

Hosmer and Lemeshow Test: Chi-square $=2.744, \mathrm{df}=7$, Sign. 0.908

Meanwhile, the variables of the income during the pandemic and the respondent's occupation show $p<0.150$. Therefore, it can be considered that both variables influenced the decision to return to farming. This finding shows that the higher the income from homestays before the pandemic, the higher the chances of working in farming. Meanwhile, the income during the pandemic appears to be negatively related to the decision to return to farming. This means that the 
respondents who receive income during the pandemic have the chance of 0.099 (odds ratio value) or rounded up to 0.10 times to return to farming. Meanwhile, the homestay owners who also do farming have the chance of 9.974 (odds ratio value) or rounded up 10 times to return to farming.

The findings above provide a plausible explanation. The higher the income before the pandemic, the higher the responsibility of the homestay owners to pay for their various life necessities. For them, the logical choice is to return to farming, which has proven to be resilient to the pandemic crisis (Gascón \& Mamani, 2021; Ratuva, 2021). The decision was also taken by the respondents whose homestays did not receive guests during the pandemic and the respondents who also work as farmers.

Khairad (2020) stated that the agricultural sector is vital to maintain food security amid a pandemic because other economic activities may be under pressure. Boughton et al. (2021) stated that the agricultural sector is not directly affected during the COVID-19 pandemic, so that it is able to survive. However, the current crisis pressure on most households and agri-food businesses may not end soon as they require a time-consuming recovery. Correspondingly, Lin \& Zhang (2020) revealed an increase in food crop production during the pandemic, although this is not the case for horticulture. During the pandemic, the roles of agropolitan areas are strengthened and agribusiness development is boosted (Ulya, 2020).

\subsection{Research Implications}

The COVID-19 pandemic has generated a significant impact on tourism activities and homestay performance. The current pandemic is still going on and we do not know when it will end. The adjustment made by the homestay owners, i.e. returning to work in farms, can be seen as a short-term measure to support their livelihoods to survive the pandemic. The implications of this study are provided in the following. It is hoped that the implications will contribute to the strengthening of business life and tourism in the village, which in turn will help the actors create economic added value.

\subsubsection{Health protocols during the COVID-19 pandemic}

The government of Gubukklakah Village ensures that health protocols, including wearing a mask, washing hands, and avoiding crowds, are implemented in various activities. Tracing, quarantine and medical treatment procedures are also imposed for people suspected of being infected with COVID-19 to suppress virus transmission. People are encouraged to immediately join the COVID-19 vaccination program currently being carried out. Even supposing that the social restrictions are removed, health and safety protocols will still be enforced on visitors and service providers. A vaccination certificate should be made a requirement for visitors to come to Gubukklakah. Visitors should be provided with information on how to carry out health procedures safely and conveniently to curb virus transmission and prevent other health risks (Bratić et al., 2021)

\subsubsection{Financial aids.}

The COVID-19 pandemic has affected homestay owners, self-employed workers and other groups of people. The decrease in the number of visits has had an impact on other economic activities, such as food and beverage businesses, trades, transportation, and logistics, which are usually served by the villagers. Although the impact of the pandemic on farming is considered relatively small compared to its 
impact on other sectors (Boughton et al., 2021), in the long term the pandemic will severely affect farming. The problems faced by farmers include the difficulty of obtaining regular foods for their households, rising food prices, and the closure or significant disruption of the markets where they buy foods and/or sell their farm products (Middendorf et al., 2021). The study by Harris et al. (2020) revealed that the majority of farming households are unable to maintain the consumption of staple foods and the adequacy of nutrient-dense foods. Therefore, they require cash or noncash assistance to reduce losses, restore business ventures, or meet children's schooling needs (Boughton et al., 2021; FAO, 2020). The assistance provided by the government is aimed at breaking the cycle of poverty and preventing the misuse of natural resources during the pandemic crisis when some people impacted by the pandemic have a tendency log forest in the BTSNP area. So far, the government has been carrying out a direct cash transfer program to affected individuals, but it is still unknown whether the financial assistance has been distributed to Gubukklakah Village.

\subsubsection{Strengthening the agricultural sector}

The agricultural sector has proven to be a lifesaver during the pandemic, especially in rural areas. It has been recognized that an integrated agricultural and rural development in the long term becomes a viable strategy to help people get out of the current crisis, create jobs, and absorb manpower, which in turn will contribute to the creation of a more robust and sustainable economy. Agricultural and rural development necessities have to be prioritized (FAO, 2020). The social values of agricultural life are able to protect people from economic losses due to the pandemic (Gascón \& Mamani, 2021; Ratuva, 2021). The elements of the agricultural sector that should be strengthened or managed well include natural resources, infrastructure, human resources, technologies, and institutions, which are very relevant to the development of rural tourism. Adaptive strategies for human resource development are aimed at building community capacity and include a training for local farmers to improve their tourism skills, which in turn will contribute to the building of a future ready workforce (Chin \& Pehin Dato Musa, 2021). Undoubtedly, the preference for rural and agricultural environments characterizes the advantages of a calm atmosphere, clean air and natural beauty over classical tourism in cities (Zhu \& Deng, 2020). The more rural environmental infrastructure is strengthened and empowered, the more service capabilities and satisfaction for tourists are generated (Coroș et al., 2021).

\subsubsection{Tourism business innovation}

One of the lessons learned from the pandemic is the requirement to reformulate tourism business concepts or practices. The pandemic is not only detrimental to the economy, but also creates anxiety due to its prolonged psychological impact. It is important that a future tourism transformation be created through cooperation between countries by applying necessary travel and health protocols (Brouder, 2020). It is necessary to rebuild trust among tourism actors who have declined to cooperate with each other due to the fear of COVID-19 transmission (Bratic et al., 2021; Zheng et al., 2021; Zhu \& Deng, 2020). Communication plays an important role in supporting the resilience of a tourist village during a pandemic (Rahmanto, 2021). Some studies (Bratić et al., 2021; Wojcieszak-Zbierska et al., 2020) showed that tourism providers and tourism destinations must adapt themselves to the changing tourist behavior, by 
providing, for examples, smaller accommodation units, isolation spaces and more outdoor tourist experiences. Vaishar \& Štastná (2020) revealed a strategy to market rural tourism, which is considered safer from virus transmission compared with urban tourism, to the domestic tourism market in Czech. Fountain (2021) also revealed a strategy to market rural tourism to the domestic tourism market in New Zealand by emphasizing garden tourism or New Zealand cuisine. A local cuisine is considered to represent an understanding of new skills, new flavors, and a new culture, which provides an experience for families. A local cuisine will provide an inclusive interpretation and connect families, friends and local communities. Like what has been done in New Zealand (see Fountain, 2021), in Gubukklakah Village, the management of rural tourism has been operating such tourist packages as garden tour, apple picking, and coffee drinking. There are many outdoor ecotourism activities around the BTSNP area offered to tourists.

\section{CONCLUSION}

Tourism activities in Gubukklakah Village carried out by its homestays showed a significant contribution to the village development. However, the COVID-19 pandemic has changed everything in the village life. About $98 \%$ of the respondents stated that the pandemic affected their homestay business activities. The respondents received information on tourism policies related to the pandemic from the village tourism organization. The respondents are highly committed to implementing health and safety protocols in providing tourism services. About $44.6 \%$ of the respondents said that the pandemic would reasonably stop, while more than $50 \%$ of them said that the pandemic would last a long time. The pandemic has reduced the number of active homestays, from 47 to 11 . Meanwhile, the number of guests, the number of occupied rooms, and the amount of income decreased by $96 \%, 83 \%$ and $81 \%$ respectively.

Responding to the pandemic, the homestay owners made some adjustments. $95.7 \%$ of them made some effort to escape from the crisis. About $85.1 \%$ of the respondents returned to agricultural businesses. Approximately $76.6 \%$ of the respondents worked in other businesses. Using a binary logistic regression approach, this study found that the variables that influenced the decision of some of the homestay owners to return to agricultural businesses are the income before the pandemic, the income during the pandemic, and the respondents' main occupation as a farmer.

The study also suggests several measures to strengthen the development of rural tourism after the COVID-19 pandemic. The first measure is implementing health protocols, such as wearing a mask, washing hands, and avoiding crowds, in performing various activities in the village. A vaccination certificate can be made a requirement for visitors to come to Gubukklakah Village. The second measure is providing cash or non-cash assistance to the villagers to reduce losses, recover business ventures, or meet children's school needs. The third measure is strengthening the agricultural and tourism sectors, including the management of natural resources, infrastructure, human resources, technologies, and institutions. In the future, there will be an increasing need for adaptive individuals with tourism skills to provide satisfactory services for tourists. The fourth measure is creating innovations and adapting to the changing tourist behavior by providing outdoor tourism products and services based on local interpretations and focusing on local uniqueness, such as local foods and farming activities. 
Author Contribution: Novi Meilana Sari: Conceptualization, Methodology, Data collection; Analysis, Writing-draft preparation; Iwan Nugroho: Conceptualization, Methodology, Writing (draft preparation, reviewing, editing); Evi Nurifah Julitasari: Writing-reviewing; Rita Hanafie: Writing-reviewing, Content analysis.

Conflict of Interest: The authors declare that they have no known competing financial interests or personal relationships that could have appeared to influence the work reported in this paper.

\section{References}

Boughton, D., Goeb, J., Lambrecht, I., Headey, D., Takeshima, H., Mahrt, K., Masias, I., Goudet, S., Ragasa, C., Maredia, M. K., Minten, B., \& Diao, X. (2021). Impacts of COVID-19 on agricultural production and food systems in late transforming Southeast Asia: The case of Myanmar. Agricultural Systems, 188. https://doi.org/10.1016/j.agsy.2020.103026

BPS. (2020a). Poncokusumo District in Figure 2020. https://malangkab.bps.go.id/publication/2020/09/28/9641fca00749babffof914 7c/kecamatan-poncokusumo-dalam-angka-2020.html

BPS. (2020b). Analisis Hasil Survei Dampak Covid-19 Terhadap Pelaku Usaha Jilid 2. BPS Pusat Jakarta. https://www.bps.go.id/publication/2020/12/21/7ec02d39d6732972dcebe54f/a nalisis-hasil-survei-dampak-covid-19-terhadap-pelaku-usaha-jilid-2.html

BPS. (2021). Laporan Perekonomian Indonesia: Dampak Adanya Program Pemulihan Ekonomi Nasional (PEN) terhadap Perekonomian Indonesia di Masa Pandemi. BPS Pusat Jakarta. BPS Pusat Jakarta. https://www.bps.go.id/publication/2021/09/17/f3ece7157064514772b18335/l aporan-perekonomian-indonesia-2021.html

Bratić, M., Radivojević, A., Stojiljković, N., Simović, O., Juvan, E., Lesjak, M., \& Podovšovnik, E. (2021). Should i stay or should i go? Tourists' covid-19 risk perception and vacation behavior shift. Sustainability (Switzerland), 13(6). https://doi.org/10.3390/su13063573

Brouder, P. (2020). Reset redux: possible evolutionary pathways towards the transformation of tourism in a COVID-19 world. Tourism Geographies, 22(3), 484-490. https://doi.org/10.1080/14616688.2020.1760928

Chin, W. L., \& Pehin Dato Musa, S. F. (2021). Agritourism resilience against Covid-19: Impacts and management strategies. Cogent Social Sciences, 7(1). https://doi.org/10.1080/23311886.2021.1950290

Coroș, M. M., Bode, O. R., Săvan, E. E., \& Ciucioiu, T. A. (2021). Rural Tourism During the Covid-19 Pandemic: A Case Study from North-Western Transylvania. Studia Universitatis Babes,-Bolyai Negotia, 66(1), 7-22. https://doi.org/10.24193/subbnegotia.2021.1.01

FAO. (2020). FAO COVID-19 Response and Recovery Programme: Economic inclusion and social protection to reduce poverty. Pro-poor COVID-19 responses for an inclusive post-pandemic economic recovery. https://doi.org/10.4060/cb3512en

Fountain, J. (2021). The future of food tourism in a post-COVID-19 world: insights from New Zealand. Journal of Tourism Futures. https://doi.org/10.1108/JTF-04-20210100

Gascón, J., \& Mamani, K. S. (2021). Community-based tourism, peasant agriculture 
and resilience in the face of COVID-19 in Peru. Journal of Agrarian Change, n/a(n/a). https://doi.org/https://doi.org/10.1111/joac.12447

Hakim, L., Siswanto, D., Rahardi, B., \& Zayadi, H. (2019). Fostering coffee agroforestry for agrotourism development in degraded land in a buffer zone of a national park: A case study from Poncokusumo, Malang, Indonesia. EurAsian Journal of BioSciences, 13(2), 1613-1620. http://www.ejobios.org/download/fosteringcoffee-agroforestry-for-agrotourism-development-in-degraded-land-in-a-bufferzone-of-a-7313.pdf

Harchandani, P., \& Shome, S. (2021). The Effects of Covid-19 on Global Tourism. ASEAN Journal on Hospitality and Tourism, 19(01), 63-83. https://doi.org/10.5614/ajht.2021.19.1.06

Harris, J., Depenbusch, L., Pal, A. A., Nair, R. M., \& Ramasamy, S. (2020). Food system disruption: initial livelihood and dietary effects of COVID-19 on vegetable producers in India. Food Security, 12(4), 841-851. https://doi.org/10.1007/s12571-020-01064-5

Kementerian Pariwisata. (2020). Tren Pariwisata 2021. Deputi Bidang Kebijakan Strategis, Kementerian Pariwisata Republik Indonesia, Jakarta. https://s3kemenparekraf.s3.ap-southeast1.amazonaws.com/Buku_Tren_Pariwisata_2122_825b87ea0f.pdf

Khaafidh, M., \& Poerwono, D. (2013). Faktor-faktor yang mempengaruhi keputusan tenaga kerja untuk berkerja di kegiatan pertanian: Studi kasus Kabupaten Rembang). Diponegoro Journal of Economics, 2, 1-13. http://ejournals1.undip.ac.id/index.php/jme

Khairad, F. (2020). Sektor Pertanian di Tengah Pandemi COVID-19 ditinjau Dari Aspek $\begin{array}{llll}\text { Agribisnis. Jurnal } & \text { 8griuma, }\end{array}$ http://www.ojs.uma.ac.id/index.php/agriuma/article/view/4357/pdf

Krisnanto, W. (2021). Perlindungan Hak Masyarakat Adat Tengger Mendapatkan Bagi Hasil Pendapatan Wisata Taman Nasional Bromo Tengger Semeru. Journal of Education, Humaniora and Social Sciences (JEHSS), 4(1), 358-364. https://doi.org/10.34007/jehss.v4i1.668

Kumar, R., Gill, S. S., \& Kunasekaran, P. (2012). Tourism as a Poverty Eradication Tool for Rural Areas in Selangor, Malaysia. Global Journal of Human Social Science, 12(7), 21-26. https://globaljournals.org/GJHSS_Volume12/4-Tourism-as-aPoverty-Eradication.pdf

Ladesta Gubukklakah. (2021). Profil Desa Wisata Gubukklakah.

Lin, B. xi, \& Zhang, Y. Y. (2020). Impact of the COVID-19 pandemic on agricultural exports. Journal of Integrative Agriculture, 19(12), 2937-2945. https://doi.org/10.1016/S2095-3119(20)63430-X

Middendorf, B. J., Faye, A., Middendorf, G., Stewart, Z. P., Jha, P. K., \& Prasad, P. V. V. (2021). Smallholder farmer perceptions about the impact of COVID-19 on agriculture and livelihoods in Senegal. Agricultural Systems, 190, 103108 https://doi.org/10.1016/j.agsy.2021.103108

Mujanah, S., Ratnawati, T., \& Andayani, S. (2015). The strategy of tourism village development in the hinterland Mount Bromo, East Java. Journal of Economics, $\begin{array}{llll}\text { Business } \& \text { Accountancy } & \text { Ventura, }\end{array}$ https://doi.org/10.14414/jebav.v18i1.385

Nugroho, I. (2010). Pengembangan Ekowisata dalam Pembangunan Daerah. Jurnal Pembangunan Daerah. 01, 65-76. Kementerian Dalam Negeri RI, Jakarta. 
https://doi.org/10.6084/m9.figshare.6268727

Nugroho, I., Hanafie, R., Negara, P. D., Sudiyono, \& Yuniar, H. R. (2021). Social Capital and Social Capacity in Rural Ecotourism Development. Indonesian Journal of Geography, 53(1), 153-164. https://doi.org/10.22146/IJG.55662

Nugroho, I., Hanafie, R., Negara, P. D., \& Yuniar, H. R. (2020). Local Capacity Building in the Ecotourism Development. International Journal of Innovative Technology and Exploring Engineering (IJITEE), 9(35), 224-228. https://doi.org/10.35940/ijitee.C1049.0193S20

Nugroho, I., \& Negara, P. D. (2014). The Role of Leadership and Innovation in Ecotourism Services Activity in Candirejo Village, Borobudur, Central Java, Indonesia. World Academy of Science, Engineering and Technology, 0079, 1178-1182. https://doi.org/10.5281/ZENOD0.1087283

Nugroho, I., \& Negara, P. D. (2015). Pengembangan Desa Melalui Ekowisata: Dilengkapi dengan peraturan perundangan tentang pedoman pengembangan desa wisata. Era Adicitra Intermedia. https://books.google.co.id/books?id=r2LMxQEACAAJ

Nugroho, I., Negara, P. D., \& Yuniar, H. R. (2018). The Planning and The Development of The Ecotourism and Tourism Village In Indonesia: A Policy Review. Journal of Socioeconomics and Development, 1(1), 43-51. https://doi.org/10.31328/jsed.v1i1.532

Prakoso, H, A. (2017). Rural tourism management strategies in Gubugklakah village, Malang, Indonesia: Road to the Asean Tourism Forum (ATF) Awards. International Journal of International Relations, Media and Mass Communication Studies, 3(6), 71-78. http://www.disparbud.jabarprov.go.id

Pratiwi, T. I., Muttaqin, T., \& Chanan, M. (2019). Pengembangan Desa Wisata Edelweiss di Desa Wonokitri Kecamatan Tosari Kabupaten Pasuruan (Resort PTN Gunung Penanjakan Taman Nasional Bromo Tengger Semeru). Journal of Forest Science Avicennia, 2(1), 16. https://doi.org/10.22219/avicennia.v2i1.8369

Purmada, D., Wilopo, W., \& Hakim, L. (2016). Pengelolaan desa wisata dalam perspektif community based tourism (Studi Kasus pada Desa Wisata Gubugklakah, Kecamatan Poncokusumo, Kabupaten Malang). Jurnal Administrasi Bisnis, 32(2), 15-22.

Purnomowati, W., Nugroho, I., \& Negara, P. D. (2012). Entrepreneurship Ability On Ecotourism Services of Local People in Bromo Tengger Semeru National Park, Malang Regency, East Java, Indonesia. 11th International Entrepreneurship Forum (11th IEF) Conference Entrepreneurship and Sustainability: From Lifestyles to Innovative Enterprises in Creative and Sustainable Environments, 36 September 2012, 458-473. https://doi.org/10.6084/m9.figshare.6267980

Puspitasari, E. A., Abdillah, Y., \& Darmawan, A. (2017). Analisis peran pendapatan masyarakat dalam perspektif bisnis pariwisata untuk pengembangan infrastruktur pariwisata (Studi pada Desa Wisata Gubugklakah Kecamatan Poncokusumo, Kabupaten Malang). Jurnal Administrasi Bisnis, 43(1), 132-137. http://administrasibisnis.studentjournal.ub.ac.id/index.php/jab/article/viewFile $/ 1706 / 2086$

Rahmanto, A. N. (2021). Crafting Normalcy: How Communication Enhances Tourist Village's Resilience during the Covid-19 Pandemic. Jurnal Komunikasi: Malaysian Journal of Communication, 37(3), 244-256. https://doi.org/10.17576/JKMJC-2021-3703-14 
Rasid, A., Mustafa, M. Z., Suradin, A., \& Hassan, R. (2012). Community Capacity Building for Sustainable Tourism Development: Experience from Miso Walai Homestay. Business and Management Review, 2(5), 10-19. https://nanopdf.com/download/community-capacity-building-for-sustainabletourism-development_pdf

Ratuva, S. (2021). COVID 19, communal capital and the moral economy: Pacific Islands responses. Cultural Dynamics, 33(3), 194-197. https://doi.org/10.1177/09213740211014312

Rouf, A., Hakim, M. L., \& Utaminingsih, A. (2018). Perubahan Sosial dan Kesejahteraan Sosial Masyarakat Desa Enclave Pasca Penetapan Taman Nasional Bromo Tengger Semeru: Studi Kasus di Desa Ngadas Kecamatan Poncokusumo Kabupaten Malang. Journal of Governance and Policy, 4(1), 1-17.

Samsudin, P. Y., \& Maliki, N. Z. (2015). Preserving Cultural Landscape in Homestay Programme Towards Sustainable Tourism: Brief Critical Review Concept. Procedia - Social and Behavioral Sciences, 170, 433-441. https://doi.org/10.1016/j.sbspro.2015.01.004

Saraithong, W., \& Chancharoenchai, K. (2014). Tourists' behaviour in Thai homestay business. International Journal of Management Cases, 13(3), 112-126. https://doi.org/10.5848/apbj.2011.00044

Setokoe, T. J., \& Ramukumba, T. (2020). Challenges of community participation in community-based tourism in rural areas. WIT Transactions on Ecology and the Environment, 248, 13-22. https://doi.org/10.2495/ST200021

Sunkar, A., Meilani, R., Rahayuningsih, T., \& Muntasib, E. K. S. H. (2016). Social Capital: a Basis for Community Participation in Fostering Environmental Education and the Heritage Tourism Development of Cibalay Megalithic Site. Journal of Tourism, 3(2), 120-129. http://ojs.unud.ac.id/index.php/eot120

Tolkach, D., \& King, B. (2015). Strengthening Community-Based Tourism in a new resource-based island nation: Why and how? Tourism Management, 48. https://doi.org/10.1016/j.tourman.2014.12.013

Ulya, H. N. (2020). Alternatif Strategi Penanganan Dampak Ekonomi Covid-19 Pemerintah Daerah Jawa Timur Pada Kawasan Agropolitan. El-Barka: Journal of Islamic Economics and Business, 3(1). https://doi.org/10.21154/elbarka.v3i1.2018

UNWTO. (2021). Tourist Arrivals Down 87\% in January 2021 as UNWTO calls for Stronger Coordination to Restart Tourism. https://www.unwto.org/news/touristarrivals-down-87-in-january-2021-as-unwto-calls-for-stronger-coordination-torestart-tourism

Vaishar, A., \& Štastná, M. (2020). Impact of the COVID-19 pandemic on rural tourism in Czechia Preliminary considerations. Current Issues in Tourism. https://doi.org/10.1080/13683500.2020.1839027

Wojcieszak-Zbierska, M. M., Jęczmyk, A., Zawadka, J., \& Uglis, J. (2020). Agritourism in the era of the coronavirus (Covid-19): A rapid assessment from Poland. $\begin{array}{lll}\text { Agriculture } \quad \text { (Switzerland), } & 10(9),\end{array}$ https://doi.org/10.3390/agriculture10090397

Zheng, D., Luo, Q., \& Ritchie, B. W. (2021). Afraid to travel after COVID-19? Selfprotection, coping and resilience against pandemic 'travel fear.' Tourism Management, 83. https://doi.org/10.1016/j.tourman.2020.104261

Zhu, H., \& Deng, F. (2020). How to influence rural tourism intention by risk knowledge 
during COVID-19 containment in China: Mediating role of risk perception and attitude. International Journal of Environmental Research and Public Health, 17(10). https://doi.org/10.3390/ijerph17103514 